\title{
Air Pollution Effects on Vegetative Growth, Fruit Quality and Mineral Composition of Washington Navel Orange
}

\section{Hala M. El-Khayat ${ }^{1}$ and Gehan R. Zaki ${ }^{2}$}

\author{
${ }^{1}$ Horticulture Research Institute, Egypt. \\ ${ }^{2}$ Professor of Occupational Hygiene and Air Pollution, High Institute of Puplic Health Alexandria \\ University, Egypt.
}

Received: 10 Nov. 2019 / Accepted 15 Jan. 2019 / Publication date: 30 Jan. 2020

\begin{abstract}
The present study was conducted during 2017 and 2018 seasons to investigate the effect of air pollution on vegetative growth, fruit quality and mineral composition of seventeen years old Washington navel orange (Citrus sinensis) budded on sour orange and growing in a private orchard located at El-Tarh, Behera governorate, Egypt . Four sites $(250,500,750,1000 \mathrm{~m})$ apart from Abou Keer Electricity company and a control site in Zahara Kafr ELdoar at a distance more than $35 \mathrm{~km}$ were selected. The data for air analysis indicated that control site gave the lowest $\mathrm{NO}_{2}, \mathrm{O}_{3}, \mathrm{TSP}$ (Total suspended particles), $\mathrm{Pb}, \mathrm{Ni}, \mathrm{Cd}$ and $\mathrm{Cr}$ whereas site one gave the highest values. Also, results showed that plants in control site gave significantly higher canopy, height and trunk increment, Leaf area, vitamin $\mathrm{C}$, total soluble solid, acidity, juice Volume, reduced sugar, non reduced sugar, total sugar, fruit diameter and fruit number, fruit and leaf nitrogen, phosphorus, potassium, leaf total chlorophyll and protein content and the lowest heavy metals content (chromium, nickel, cadmium and lead) in leaf and fruit than other sites. As well as these parameters increased by increasing the distance from the pollutant source whereas heavy metals decreased. Fore thus, it can be recommended to avoid adhesive plantings less than $0-1000 \mathrm{~m}$ distances from the pollutant source due to heavy metals contamination in order in order to preserve both agriculture and environment.
\end{abstract}

Keywords: air pollution, navel orange, heavy metals, Fruit Quality

\section{Introduction}

The owners of a citrus farms complained from annual great citrus crops' damage since the foundation of the opposite power plant that uses Mazot for electricity generation. Their grievances were the dark spots on the fruits. This made them useless. Air pollutants (AP) are substances that modify the structure of the atmosphere. They usually result from both natural and man-made sources. The first comprises volcanoes, earthquakes, forest fires, and storms. The second includes transportation, power generation, industries, and solid waste disposal (Haryanto, 2012). Mazot is a heavy fuel oil that remains after fractional distillation of petroleum as a viscous liquid. Its combustion releases particulate matters, sulfur dioxide $\left(\mathrm{SO}_{2}\right)$, carbon monoxide $(\mathrm{CO})$, heavy metals as primary pollutants; ozone $\left(\mathrm{O}_{3}\right)$ as a secondary pollutant; and nitrogen dioxide that represents both primary and secondary types (Fritt-Rasmussen et al., 2018)

Citrus aurantium $\mathrm{L}$ is sensitive to extraordinary concentrations of airborne heavy metals, which lead to leaf burning, retarded growth and yellowing starting at the tip. In addition, the yellowing is very bright and spread over the leaves. In severe cases, secretion spots are seen on the lower leaf surfaces with leaf drop before maturity. Leaf drop is heavy, then dieback follows. Other symptoms can comprise twig dieback; feeder roots can also convert darkened, and restricted growth exhibited. Many changes occur in chlorophyll content, lipid content and losses of polypeptides indicated in photochemical accomplishments and damage to DNA molecules (Kabata-Pendias 2011). In Citrus aurantium possibly chromium and nickel formed strong complexes with ligands. Generally, Heavy metals include lead $(\mathrm{Pb})$, nickel $(\mathrm{Ni})$, cadmium $(\mathrm{Cd})$ and chromium $(\mathrm{Cr})$ are toxic elements at higher concentrations, these groups of heavy metals can lead to poisoning. High contents of heavy metals $(\mathrm{Pb}$ and $\mathrm{Cd}$ ) in fruits were correlated to high occurrence of upper intestinal cancer (Turkdogan et al., 2002). Lead unconfined from exhaust releases into atmosphere can be dropped in leaf surface and adsorbed inside plant cells Ogbonna, and Okezie, (2011) and effects a lot of cytoplasmic enzymes

Corresponding Author: Hala M. El-Khayat, Horticulture Research Institute, Egypt.

E-mail: elkhayat_h_m66@yahoo.com 
also, leads to inhabitation of synthesis of hemoglobin, cardiovascular system and acute chronic destruction to the central nervous system and outlying nervous system Ogwuegbu and Muhanga, (2005). Cadmium has no identified bio importance in human bio chemistry and physiology and ingesting even at very little concentration can be toxic Nolan (2003) and Young (2005). The reference standards for nickel in healthy adults are $0.2 \mu \mathrm{g} / \mathrm{L}$ in serum and $1-3 \mu \mathrm{g} / \mathrm{L}$ in urine (B. Hafeez1 2012). Exists of nickel produced a decrease in body weights, significantly increased heart and decreased liver weights. The carcinogenicity of nickel compounds which happens through breath mainly as a result of occupational exposures ( Nielsen, 1974). Valued Safe and Suitable Daily Dietary Intake (ESADDI) from chromium bar day about $10-200 \mu \mathrm{g} /$ day different age over of this dose caused weakened resistant systems, liver and Kidney damage, Change of genetic substantial, Lung cancer and Death (Guerin 2004).

Standard concentrations of $\mathrm{Cd}, \mathrm{Cr}, \mathrm{Ni}, \mathrm{Pb}$ in vegetables and fruits are normally $<0.5,2-20,1-$ 10, 6-9 ppm respectively (Manahan 2001). Cadmium concentrations in tree leaves ranged from 0.23 to $1.22 \mathrm{ppm}$ by Citrus aurantium. Whereas, chromium concentrations is M.V. $16.14 \mathrm{ppm}$. The lead content of tree leaves in Citrus aurantium is (M.V. 30.5 ppm). In addition, Nickel concentrations in tree leaves is M.V. 26.16 ppm, (Greger1999). Safe limit in Citrus reticulata and Citrus sinensis for lead and Cadmium are 1.5 and $2.5(\mathrm{mg} / \mathrm{kg}$ ) (WHO, 2007).

Amer et al. (2019) reported that detection limits of heavy metals were 0.1, 0.02, 0.1 and 0.06 $\mathrm{mg} / \mathrm{kg}$ for $\mathrm{Pb}, \mathrm{Cd}, \mathrm{Ni}$ and $\mathrm{Cr}$, respectively. Furthermore, Amer et al. (2019) concentrated heavy metals $(\mathrm{mg} / \mathrm{kg})$ in orange samples collected from four Egyptian governorates. They found that $\mathrm{Ni}$ was also detected in orange samples at a concentration of 031 , and $0.38 \mathrm{mg} / \mathrm{kg}$ from Cairo and Giza governorates respectively. Nickel was also detected in orange below the maximum residue limit $(0.20$ $\mathrm{mg} / \mathrm{kg}$ ) for samples obtained from Alexandria and El-Fayoum governorates $(0.16$ and $0.06 \mathrm{mg} / \mathrm{kg})$. Moreover, Maximum residue limit was 0.05 and 0.1 for cadmium and lead (European commission 1881/2006-629/2008) and 0.1 and 0.2 for chromium and nickel, respectively (WHO/FAO). In addition, permissible levels allowed in food $(\mathrm{mg} / \mathrm{kg}$ ) were $0.2,0.3$ and 66.9 for cadmium, lead, and nickel, respectively (WHO/FAO). The aim of this study is to assess the impacts of air pollutants on citrus crops.

The aim of this study is to assess the impacts of air pollution released from Abou Keer Electricity Company Mazot exhausts on vegetative growth, fruit quality, mineral composition and concentrations of some heavy metals i.e. Lead $(\mathrm{Pb})$, (Nickel $(\mathrm{Ni})$, Cadmium $(\mathrm{Cd})$, and chromium $(\mathrm{Cr})$, and their effects on Washington Navel orange.

\section{Materials and Methods}

The present study was conducted in 2017 and 2018 seasons to study the effect of Abou Keer Electricity Company Mazot exhausts on seventeen years old Washington Navel orange (Citrus Sinensis) budded on sour orange cultivated in private orchard located in El-Tarh, Behera governorate ,Egypt to determine fruit quality, the concentrations of some heavy metals (Nickel (Ni), Cadmium $(\mathrm{Cd})$, Lead $(\mathrm{Pb})$ and chromium $(\mathrm{Cr})$ in the areas near to Abou Keer Electricity Company exhausts.

\section{Sampling sites}

One of unpolluted site (control) away from Abou Keer electricity company was chosen for comparison as a control in Zahara Kafr E ldour opposite to Abou Keer electricity company on the agricultural road at a distance more than $35 \mathrm{~km}$. Four sites with gradual distances from Abou Keer Electricity Company were chosen for sampling:

-Control site was $31.141936 \mathrm{~N}, 30.132995 \mathrm{E}$ and at distance about more than $35 \mathrm{~km}$ from pollutant source

-Site 1 was at $31^{\circ} 15^{`} 58.87^{\prime} \mathrm{N}$, and $30^{\circ} 8^{`} 45.10^{\prime}$ Eat distance about $250 \mathrm{~m}$.

-Site 2 was at $\mathrm{N} 31^{\circ} 15^{`} 54.4$, and $\mathrm{E} 30^{\circ} 8^{`} 43.6$ at distance about $500 \mathrm{~m}$.

-Site 3 was at $\mathrm{N} 31^{\circ} 15^{`} 54.33$, and $\mathrm{E} 30^{\circ} 8^{`} 48.91$ at distance about $750 \mathrm{~m}$.

-Site 4 was at $\mathrm{N} 31^{\circ} 15^{`} 51.22$, and $\mathrm{E} 30^{\circ} 8^{`} 49.67$ at distance about $1 \mathrm{~km}$. The average of temperature was $18.5-28$, the average relative humidity was $60 \%$ and the wind speed was $4 \mathrm{~km} /$ hour. 

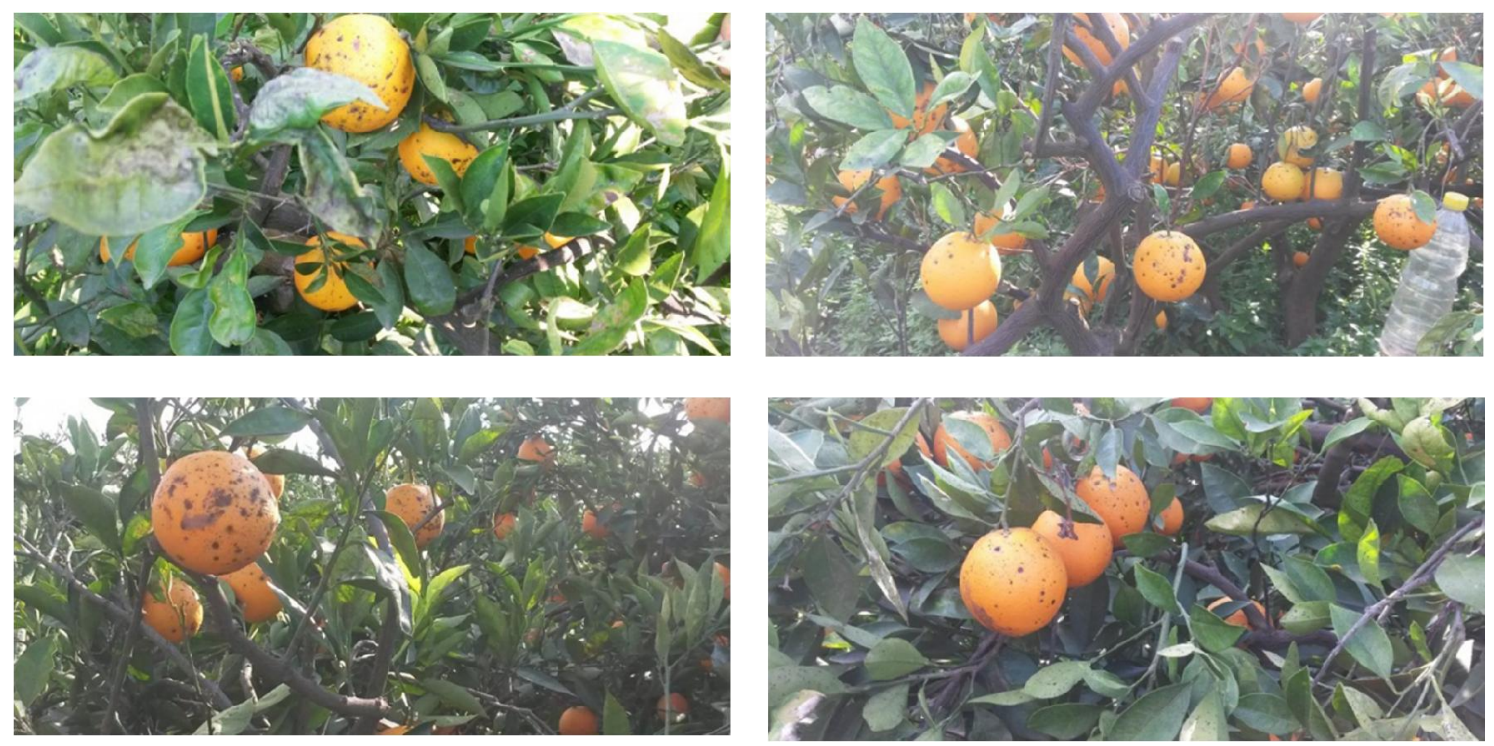

Symptoms of air pollution on vegetative growth and fruits of orange in selected areas

At experimental sites five air station was designed for collection of control and four criteria air pollutants including Gas concentration $\mu \mathrm{g} / \mathrm{m}^{3}, \mathrm{SO}_{2}, \mathrm{NO}_{2}, \mathrm{O}_{3}$ were sampled using air sampling train for 24 hours according to Improved West and Gaeke Method, Modified Jacob \& Hochheiser Method (NaOH-NaAsO ${ }_{2}$ ) Method and Method 411, Air Sampling and Analysis,( Potassium Iodide Method" for one hour) respectively and TSP (Total suspended particles ) were sampled using High volume air sampler model TE-5170XZ-USA according to Compendium of Method for Determination of Inorganic Compound in Ambient Air (10-2.1) for continuous 24 hours (IO-2.1 Sampling of Ambient Air for Total Suspended Particulate ) and heavy metals $\mathrm{ml} \mathrm{gm} / \mathrm{L}(\mathrm{Pb}, \mathrm{Ni}, \mathrm{Cd}$, and $\mathrm{Cr}$ ) were determine according to the Atomic Absorption Spectroscopy (AAS) technique, AAS/ICP Method after sampling on equivalent filter paper in December 2017, June 2018 and December 2018. Citrus leaf and fruit samples were gathered at the same dimensions.

Table 1: Maximum limit of Emissions (gases, Lead and Solid Particles) from Mazot and natural gas.

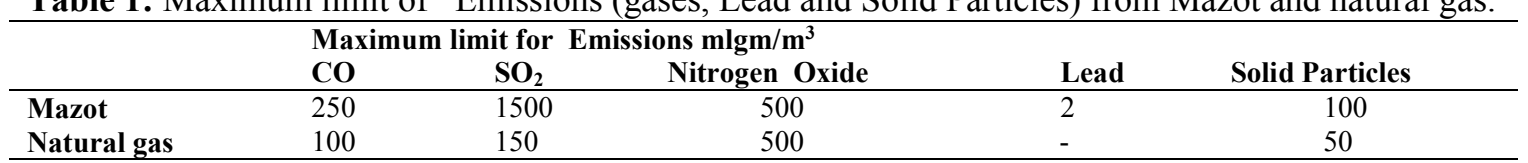

Egyptian Fact No 44 (continued) June 23, 2012.

Table 2: Allowed limit for Gas concentration and heavy metals

\begin{tabular}{cccccccc}
\hline \multicolumn{2}{l}{ Allowed limit for Gas concentration } & $\boldsymbol{\mu} \boldsymbol{g} / \boldsymbol{m}^{3}$ & \multicolumn{3}{c}{ Max limit for heavy metal $\mathbf{~ m l ~} \mathbf{g m} / \mathbf{L}$} \\
\hline $\mathrm{SO}_{2}$ & $\mathrm{NO}_{2}$ & $\mathrm{O}_{3}$ & $* \mathrm{TSP}$ & $\mathrm{Pb}$ & $\mathrm{Ni}$ & $\mathrm{Cd}$ & $\mathrm{Cr}$ \\
150.0 & 150.0 & 180.0 & 230.0 & 0.01 & 0.1 & 0.01 & 0.01 \\
\hline
\end{tabular}

*(Total suspended particles) $\mu \mathrm{g} / \mathrm{m}^{3}$

The maximum allowable according to the Environmental Law No. 9 of 2009 and its executive regulations issued by the decisions of the Prime Minister No. 1095-2011, 710-2012.

\section{Vegetative growth parameters:}

Vegetative growth parameters were measured in January 2017, December 2017 and December 2018. Tree height increment $(\mathrm{cm})$, trunk increment $(\mathrm{cm})($ trunk across was measured at $20 \mathrm{~cm}$ above the budding zone, Canopy increment (m) were calculated .Average leaf area at the end of spring growth cycle (September) was calculated using the equation of (Chou, 1966). Leaf area $=2 / 3$ length $\times$ width.

\section{Leaves and Fruit sampling:}

Forty mature leaves at different four sites of each tree were collected at September of both seasons a sample of twenty leaves from previous spring growth were randomly selected and 
collected from the middle part of non-fruiting non flushing shoots, of each tree according to Jones and Embleton, (1960). Total Chlorophyll was determined (SPAV Unite) according to Yadava (1996) using Mimolta SPAV Chlorophyll meter model. Leaf protein content $(\mu \mathrm{g} / \mathrm{g})$ was measured according to Biuret method and preparation of reagents was done according to Layne (1957).2At harvest stage 15 fruits were collected from each replicate to determine the effect of air pollution at different sites on fruit quality characteristics. All samples were collected for two seasons in December 2015 and 2016.

The leaves were then washed with tap and distilled water then fruit tissues and leaves oven dried at $65-70^{\circ} \mathrm{c}$ to a constant weight. The dried leaf and fruit tissues were ground and digested with sulphuric acid and hydrogen peroxide as mentioned by Evenhius and Dewaard (1980). In the digested solution, total nitrogen and phosphorus were determined calorimetrically according to Evenhuis (1976) and Murphy and Riley (1962), respectively. Potassium and sodium were determined by a flame photometer according to Brown and Lilliland, (1966). Concentration of heavy metals $(\mathrm{Ni}, \mathrm{Pb}$, $\mathrm{Cd}$ and $\mathrm{Cu}$ ) using AAS device. The plant samples were prepared for measuring according to (APHA, 1998).

The percentage of total soluble solids (TSS\%) were determined with a hand refractometer according to A.O.A.C.(1995). Total acidity \% as citric acid were calculated according to A.O.A.C, (1995). Vitamin C was calculated as $\mathrm{mg} / 100 \mathrm{ml}$ juice according to Horwitz, (1972).

\section{Statistical Analysis:}

One-way analyses of variance (ANOVA) were performed to test the differences. All data obtained were statistically analyzed according to Snedecor and Cochran (1990) using the SAS version program (SAS, 2000).

\section{Results and Discussion}

\section{Air analysis:}

Concerning air analysis in Table (3) it is obvious that $\mathrm{SO}_{2}, \mathrm{NO}_{2}, \mathrm{O}_{3}$, TSP and heavy metals $(\mathrm{Pb}$, $\mathrm{Ni}, \mathrm{Cd}$ and $\mathrm{Cr}$ ) in four studied sites were greatly higher than that at control site at different sampling periods. This may be attributed to the presence of power generation facility that uses mazot fuel facing sites 1.2, 3 and 4, while the only observed at pollutants levels (Aps) during December 2017 $\left(141.6,197.3,266.8\right.$ and $309.8 \mu \mathrm{g} / \mathrm{m}^{3}$ or $6.35,0.29,2.2$ and $\left.0.22 \mathrm{mlgm} / \mathrm{L}\right)$, June2018 $(138.4,193.2$, 261.8 and $315.6 \mu \mathrm{g} / \mathrm{m}^{3}$ and $5.33,0.28,3.16$ and $\left.0.14 \mathrm{ml} \mathrm{gm} / \mathrm{L}\right)$ and December 2018 (139.1 $194.3,263.4$ and $311.5 \mu \mathrm{g} / \mathrm{m}^{3}$ and $\left.5.88,0.279,2.73,0.16 \mathrm{ml} \mathrm{mg} / \mathrm{L}\right)$ respectively. They were more than the allowed limited $\left(150,150.0,180.0\right.$ and $230.0 \mu \mathrm{g} / \mathrm{m}^{3}$ and $0.01,0.1,0.01$ and $0.01 \mathrm{mlmg} / \mathrm{L}$ respectively). However, mazot fuel is a source of $\mathrm{SO}_{2}$, it was in the allowed limited (150.0. $\mathrm{n} \mathrm{\mu g} /$ $\mathrm{m}^{3}$ ). This can be explained based on its lowest physical distance from the source .Accordingly, control site was the lowest Aps followed by 4, 3, 2 and 1 respectively. The pollution levels four sites were higher than the National Ambient Air Quality Standard, while they were lower in control site. In addition, mazot combustion is one of the major source of sulfur dioxide especially, after desulfurization of the transportation fuels in Egypt ambient air pollutants at the four sites.This is compliant with results of Goudarzi et al. (2016) mention that control of sulfur dioxide in atmosphere can be conducted by replacement of mazot fuel. Moreover, Higazy et al. (2019) reported that using mazot reveals very high levels of $\mathrm{SO}_{2}$ and $\mathrm{NO}_{2}$ emissions. In addition, $\mathrm{Li}$ et al. (2018) illustrated that the highest concentration of air pollutants, containing $\mathrm{SO}_{2}$, and $\mathrm{CO}_{2}$, were removed to other areas by interprovincial electricity transmissions. Also, Ishtiag et al. (2012) stated that places nearby a mazot power generation facility are affected by the exposure to $\mathrm{SO}_{2}, \mathrm{NO}_{2}, \mathrm{O}_{3}$, TSP. Furthermore, Abdalla (2015) indicated that $\mathrm{SO}_{2}$ and accordingly $\mathrm{NO}_{2}$ may increase the atmospheric and soil acidity which may negatively affecting the plants production.

With respect to Skinder et al. (2014), Kanabkaew et al. (2015), and Hoang Anh Le and Kim Oanh (2010). They reported that using biomass fuel is the cleanest way of pollutant source production. 
Table 3: Concentrations of ambient air pollutants at the sites facing power generation company (using Mazot fuel) and at a control site.

\begin{tabular}{|c|c|c|c|c|c|c|c|c|}
\hline \multicolumn{5}{|c|}{ Gas concentration $\mu \mathrm{g} / \mathrm{m}^{3}$ at experiment sites } & \multicolumn{4}{|c|}{ Heavy metal $\mathrm{ml}$ gm /L at experiment sites } \\
\hline Sites & $\mathrm{SO}_{2}$ & $\mathrm{NO}_{2}$ & $\mathbf{O}_{3}$ & *TSP & $\mathbf{P b}$ & $\mathrm{Ni}$ & Cd & $\mathrm{Cr}$ \\
\hline \multicolumn{9}{|c|}{ December 2017} \\
\hline Control & 30 & 39 & 50 & 61.2 & 0.06 & 0.01 & 0.01 & 0.01 \\
\hline Site $2(500 \mathrm{~m})$ & 135.8 & 191.1 & 233.8 & 284.3 & 2.37 & 0.22 & 1.77 & 0.12 \\
\hline Site $3(750 \mathrm{~m})$ & 127.8 & 164.8 & 215.9 & 268.3 & 2.37 & 0.17 & 0.94 & 0.06 \\
\hline Site $4(1 \mathrm{~km})$ & 119.4 & 149.9 & 193.6 & 238.4 & 01.52 & 0.06 & 0.62 & 0.02 \\
\hline Control & 29 & 37 & 49 & 62 & 0.052 & 0.014 & 0.019 & 0.01 \\
\hline Site $1(250 \mathrm{~m})$ & 138.4 & 193.2 & 261.8 & 315.6 & 5.33 & 0.28 & 3.16 & 0.14 \\
\hline Site $2(500 \mathrm{~m})$ & 122.7 & 186.5 & 239.7 & 298.4 & 2.37 & 0.25 & 1.70 & 0.10 \\
\hline Site $3(750 \mathrm{~m})$ & 116.5 & 169.6 & 218.4 & 256.7 & 1.57 & 0.23 & 1.27 & 0.07 \\
\hline Site $4(1 \mathrm{~km})$ & 107.8 & 154.8 & 199.2 & 234.4 & 1.06 & 0.06 & 0.51 & 0.03 \\
\hline Site3 (750m) & 123.1 & 165.7 & 215.9 & 263.1 & 1.95 & 0.21 & 1.12 & 0.063 \\
\hline Site $4(1 \mathrm{~km})$ & 114.2 & 153.1 & 197.3 & 235.9 & 1.3 & 0.06 & 0.5 & 0.02 \\
\hline
\end{tabular}

- (Total suspended particles) $\mu \mathrm{g} / \mathrm{m}^{3}$

\section{Vegetative growth:}

Concerning vegetative growth data of Washington navel orange plants in Table (4), it was cleared that the control showed significantly higher canopy, height, trunk increment and Leaf area values when compared with other sites. Also, significant differences were found among the four sites in vegetative growth studied parameters which improved by increasing distance from the electricity power station in both seasons.

Table 4: Effects of air pollution on tree canopy, height and trunk increment and leaf area of Washington navel orange at different sites under study.

\begin{tabular}{lcccccccc}
\hline \multicolumn{1}{c}{ Sites } & \multicolumn{2}{c}{ Canopy increment } & \multicolumn{2}{c}{ Height increment } & \multicolumn{2}{c}{ Trunk increment } & \multicolumn{2}{c}{ Leaf area $\left(\mathbf{c m}^{\mathbf{2}}\right)$} \\
& $\mathbf{2 0 1 7}$ & $\mathbf{2 0 1 8}$ & $\mathbf{2 0 1 7}$ & $\mathbf{2 0 1 8}$ & $\mathbf{2 0 1 7}$ & $\mathbf{2 0 1 8}$ & $\mathbf{2 0 1 7}$ & $\mathbf{2 0 1 8}$ \\
\hline Control site & $0.073 \mathrm{a}$ & $0.076 \mathrm{a}$ & $0.082 \mathrm{a}$ & $0.0813 \mathrm{a}$ & $0.071 \mathrm{a}$ & $0.073 \mathrm{a}$ & $18.5 \mathrm{a}$ & $18.1 \mathrm{a}$ \\
Site 1 & $0.0244 \mathrm{e}$ & $0.022 \mathrm{e}$ & $0.0478 \mathrm{e}$ & $0.042 \mathrm{e}$ & $0.0297 \mathrm{e}$ & $0.0287 \mathrm{e}$ & $7.3 \mathrm{e}$ & $5.69 \mathrm{e}$ \\
Site 2 & $0.0472 \mathrm{~d}$ & $0.044 \mathrm{~d}$ & $0.0552 \mathrm{~d}$ & $0.0543 \mathrm{~d}$ & $0.0396 \mathrm{~d}$ & $0.0371 \mathrm{~d}$ & $9.8 \mathrm{~d}$ & $8.78 \mathrm{~d}$ \\
Site3 & $0.0513 \mathrm{c}$ & $0.059 \mathrm{c}$ & $0.0671 \mathrm{c}$ & $0.06 \mathrm{c}$ & $0.0465 \mathrm{c}$ & $0.045 \mathrm{c}$ & $12.7 \mathrm{c}$ & $11.34 \mathrm{c}$ \\
Site4 & $0.064 \mathrm{~b}$ & $0.062 \mathrm{~b}$ & $0.073 \mathrm{~b}$ & $0.067 \mathrm{~b}$ & $0.061 \mathrm{~b}$ & $0.0577 \mathrm{~b}$ & $15.6 \mathrm{~b}$ & $14.48 \mathrm{~b}$ \\
LSD 0.05 & 0.002 & 0.0022 & 0.0028 & 0.0014 & 0.008 & 0.004 & 0.084 & 0.185 \\
\hline
\end{tabular}

These findings are in harmony with those obtained by Polle et al. (1992) on street trees (Canas et al., (1997) on banana plants. Fahmyi et al. (2004) on Norwa spruce trees reported a reduction in leaf area due to the effect of different air pollutants. The specific leaf area, of the target plants were decreased in the pollution sites compared to the plants growing in non-polluted sites. Also, Bhardwaj et al. (2009) illustrated that with increasing $\mathrm{Pb}$ and $\mathrm{Cd}$ concentrations, there was a gradual decrease in tree height and leaf area. In addition, Zafar et al. (2016) found that the exhaust emission treatment caused a significant decrease in leaf area of $V$. rosea and $R$. tuberosa.

\section{Total chlorophyll and Protein:}

The results in Table (5) revealed that the total chlorophyll and Protein content in the leaves of Washington navel orange in the control site was higher than the four sites with a significant difference. Moreover, there were significant differences among the four sites and the fourth site had higher Total chlorophyll and Protein content than others. These result meet with the results of Mehlhorn et al. (1988) who found that the reduction in photosynthetic pigments under the influence of air pollutants has been extensively cited as a reliable symptom of foliar damage. Canas et al. (1997) who pointed out that air pollution diminishes the contents of chlorophylls a and the observed reduction of photosynthetic pigments of corn and banana plants which may be explained on the basis 
of the breakdown of chlorophyll molecules in a way similar to that in the senescent leaves. As well as, Kevresan et al. (2001) who found that the increasing in the metal accumulation in the plant leaves, has an effect on the plant development, biomass, protein and chlorophyll content. Also, Prasad and Prasad and Kastori et al., (1992) reported that content of soluble proteins decreased with high concentration of heavy metals. Moreover, Touchette and Burkholder (2002) found that proteins in plants increased with the progression growing season. Al-Sallihy et al. (2016) who found a higher decrease with a significant difference in protein content was in sites 1 and 2 compared to site 3 and the control site because of the increasing of pollutants. As well as, Fahmyi et al. (2004) stated that the contents of photosynthetic pigments and soluble proteins in the leaf tissues of the target plants were decreased in the polluted sites compared to the plants growing in non-polluted sites. Peralta-Videa et al. (2004) and Kiran and Sahin (2005) stated that in addition to the effects of heavy metals on physiological and morphological characteristics of plants like inhibition of seed germination and rootshoot development happen. These elements caused a major biochemical changes such as the formation of reactive oxygen species (ROS) that resulted in altered levels of enzymatic and non-enzymatic antioxidants, and depression of plant proteins and pigment content. Furthermore, Yurekli and Porgali (2006); Bhardwaj et al. (2009) and Doganlar et al. (2012) found that heavy metals caused a decrease in the content of photosynthetic pigment in many plant species including Citrus aurantium L. due to the peroxidation of the photosynthetic membrane and inhibition of chlorophyll biosynthesis enzymes Also, Bhardwaj et al. (2009) found that the protein content as well as photosynthetic pigments were decreased as concentrations of heavy metals increased in comparison with the control plants and minimum protein concentration was noted in plants at the highest concentration of $\mathrm{Pb}$ and $\mathrm{Cd}$.

In addition, Doganlar and Atimaca (2011) reported that chlorophyll content was decreased 15 $66 \%$ in industrial and urban street plants as a result of air pollutants and heavy metals such as $\mathrm{Ni}, \mathrm{Pb}$ and Zn. Safawi et al. (2014) reported that chlorophyll synthesis is breakdown in plants as an effect of an elevation of heavy metals in this site and a decrease in the chlorophyll content was detected in parallel with an increasing in the pollution level.

In this respect, Prasad and Prasad (1987) reported that $\mathrm{Pb}$ also distorts the membrane structure of chloroplasts, which ultimately leads to decrease in Chl. content while Bhardwaj et al. (2009) illustrated that the levels of photosynthetic pigments, namely Chl. 'a' and Chl ' $b$ ' decreased as the concentrations of $\mathrm{Pb}$ and $\mathrm{Cd}$ in soil increased. Lead was found to inhibit $\delta$ amino levulinic acid dehydratase activity in mung bean resulting in a decrease in Chl. content. Protein content under heavy metal influence may be affected due to enhancing protein hydrolysis resulting in decreased concentration of soluble proteins Melnichuk et al., 1982).

\section{Leaf mineral compositions:}

Regarding leaf nitrogen, phosphorus and potassium of Washington navel orange, the data in Table (5) indicated that control plant had significantly higher leaf nitrogen, phosphorus and potassium than plants in other sites. In addition, leaf nitrogen, phosphorus and potassium increased significantly by increasing distance. These findings agree with the results of Young and Young (2001) who found that air pollution lowers the total $\mathrm{N}$ content in soil, as supply of this element in soil. This trend is reduced with the distance because of the lower dumping of fly ash. On other hand, Luo et al. (2009) reported that fly ash or coal ash contains an appreciable amount of micro nutrients therefore, when they fall in some places and the accumulation of these elements must be higher.

Table 5: Effects of air pollution on leaf total Chlorophyll, Protein, nitrogen, phosphorus and potassium of Washington navel orange at different sites under study.

\begin{tabular}{llllllllllll}
\hline Sites & \multicolumn{2}{c}{$\begin{array}{c}\text { Total Chlorophyll } \\
\text { SPAV unite }\end{array}$} & \multicolumn{2}{c}{ Protein $(\boldsymbol{\mu g} / \mathbf{g})$} & \multicolumn{2}{c}{ N\% } & \multicolumn{2}{c}{ P\% } & \multirow{2}{*}{ K\% } \\
\hline & $\mathbf{2 0 1 7}$ & $\mathbf{2 0 1 8}$ & $\mathbf{2 0 1 7}$ & $\mathbf{2 0 1 8}$ & $\mathbf{2 0 1 7}$ & $\mathbf{2 0 1 8}$ & $\mathbf{2 0 1 7}$ & $\mathbf{2 0 1 8}$ & $\mathbf{2 0 1 7}$ & $\mathbf{2 0 1 8}$ \\
\hline Control & $64.1 \mathrm{a}$ & $62.3 \mathrm{a}$ & $312 \mathrm{a}$ & $300 \mathrm{a}$ & $2.8 \mathrm{a}$ & $2.7 \mathrm{a}$ & $0.862 \mathrm{a}$ & $0.85 \mathrm{a}$ & $1.39 \mathrm{a}$ & $1.32 \mathrm{a}$ \\
Site 1 & $48.56 \mathrm{e}$ & $49.41 \mathrm{e}$ & $254.3 \mathrm{e}$ & $246.9 \mathrm{e}$ & $2.09 \mathrm{e}$ & $1.94 \mathrm{e}$ & $501 \mathrm{e}$ & $0.492 \mathrm{e}$ & $0.44 \mathrm{e}$ & $0.35 \mathrm{e}$ \\
Site 2 & $53.4 \mathrm{~d}$ & $53.77 \mathrm{~d}$ & $266.45 \mathrm{~d}$ & $258.6 \mathrm{~d}$ & $2.22 \mathrm{~d}$ & $2.08 \mathrm{~d}$ & $0.592 \mathrm{~d}$ & $0.585 \mathrm{~d}$ & $0.66 \mathrm{~d}$ & $0.6 \mathrm{~d}$ \\
Site 3 & $55.6 \mathrm{c}$ & $56.1 \mathrm{c}$ & $281.35 \mathrm{c}$ & $275.3 \mathrm{c}$ & $2.34 \mathrm{c}$ & $2.29 \mathrm{c}$ & $0.67 \mathrm{c}$ & $0.63 \mathrm{c}$ & $0.86 \mathrm{c}$ & $0.8 \mathrm{c}$ \\
Site 4 & $58.25 \mathrm{~b}$ & $59.34 \mathrm{~b}$ & $300.14 \mathrm{~b}$ & $294.3 \mathrm{~b}$ & $2.6 \mathrm{~b}$ & $2.54 \mathrm{~b}$ & $0.698 \mathrm{~b}$ & $0.675 \mathrm{~b}$ & $0.95 \mathrm{~b}$ & $0.91 \mathrm{~b}$ \\
LSD 0.05 & 0.152 & 0.202 & 0.885 & 0.776 & 0.075 & 0.067 & 0.005 & 0.006 & 0.01 & 0.0103 \\
\hline
\end{tabular}


Concerning, leaf chromium, nickel, cadmium and lead of Washington navel orange, the data in Table (6) illustrated that site one gave significantly higher heavy metals (chromium, nickel, cadmium and lead) in leaves as compared with control and the other three sites in both seasons .Also, there were significantly differences in leaf chromium, nickel, cadmium and lead content among the three other sites whereas, control plants had significantly the lowest leaf chromium, nickel, cadmium and lead. Canas et al. (1997) reported that banana and corn plants exposed to air pollutants, lead can be found in nature in higher concentrations than the other three analyses metals, most of the emissions originating from industry. While, Kabata-Pendias (2011) reported that in general, plants readily take up the heavy metals dissolved in soil solutions, and it also may absorb heavy metals by aboveground parts from aerial deposition. In addition, Al-Safawi et al. (2014) found that the Citrus trees which grow in the industrial areas and main streets were containing high concentrations of heavy metals in their tissues. As well as, the exclusion of $\mathrm{Pb}$ from fuels resulted in a significant decrease of its concentrations (European Environmental Agency, 2018).

Table 6: Effects of air pollution on leaf chromium, nickel, cadmium and lead of Washington navel orange at different sites under study.

\begin{tabular}{lcccccccc}
\hline Sites & \multicolumn{2}{c}{ Pb (ppm) } & \multicolumn{2}{c}{ Ni (ppm) } & \multicolumn{2}{c}{ Cd (ppm) } & \multicolumn{2}{c}{ Cr (ppm) } \\
& $\mathbf{2 0 1 7}$ & $\mathbf{2 0 1 8}$ & $\mathbf{2 0 1 7}$ & $\mathbf{2 0 1 8}$ & $\mathbf{2 0 1 7}$ & $\mathbf{2 0 1 8}$ & $\mathbf{2 0 1 7}$ & $\mathbf{2 0 1 8}$ \\
\hline Control & $7.1 \mathrm{e}$ & $7.6 \mathrm{e}$ & $4.7 \mathrm{e}$ & $5.3 \mathrm{e}$ & $0.97 \mathrm{e}$ & $1.1 \mathrm{e}$ & $4 \mathrm{~d}$ & $4.6 \mathrm{~d}$ \\
Site 1 & $1136.2 \mathrm{a}$ & $1268 \mathrm{a}$ & $150.7 \mathrm{a}$ & $164.13 \mathrm{a}$ & $44.7 \mathrm{a}$ & $45.2 \mathrm{a}$ & $310 \mathrm{a}$ & $312 \mathrm{a}$ \\
Site 2 & 920.67 & $983.8 \mathrm{~b}$ & $141.2 \mathrm{~b}$ & $147.57 \mathrm{~b}$ & $38.8 \mathrm{~b}$ & $39.2 \mathrm{~b}$ & $298 \mathrm{~b}$ & $299.37 \mathrm{~b}$ \\
Site3 & $797.8 \mathrm{c}$ & $798 \mathrm{c}$ & $126.7 \mathrm{c}$ & $138.2 \mathrm{c}$ & $34.53 \mathrm{c}$ & $35.6 \mathrm{c}$ & $297.6 \mathrm{~b}$ & $298.1 \mathrm{~b}$ \\
Site4 & $588.6 \mathrm{~d}$ & $624.1 \mathrm{~d}$ & $111.5 \mathrm{~d}$ & $114.2 \mathrm{~d}$ & $13.2 \mathrm{~d}$ & $14.8 \mathrm{~d}$ & $290 \mathrm{c}$ & $295.13 \mathrm{c}$ \\
LSD $_{\mathbf{0 . 0 5}}$ & 2.36 & 1.25 & 0.868 & 1.28 & 0.235 & 1.24 & 1.88 & 1.43 \\
\hline
\end{tabular}

\section{Fruit Quality:}

As for fruit length, fruit diameter and fruit number of Washington navel orange were shown in Table (7). Control plants had the highest fruit length in the second season and the highest fruit diameter and fruit number in both seasons. Also, significant differences were found among the four sites in fruit length, fruit diameter and fruit number which increased by increasing distance from the electricity power station in both seasons . Similar results were summarized by Grant and Lafond (1993) who found that due to a low quantity of allowed biological matter, crop yield in the closer zones from pollutant source is decline.

Table 7: Effects of air pollution on Fruit Length, Fruit Diameter and Fruit Number of Washington navel orange at different sites under study.

\begin{tabular}{lcccccc}
\hline Sites & \multicolumn{3}{c}{ Fruit Shape Index } & \multicolumn{2}{c}{ Fruit Number } \\
\cline { 2 - 5 } & \multicolumn{2}{c}{ Fruit Length(mm) } & \multicolumn{2}{c}{ Fruit Diameter(mm) } & & $\mathbf{2 0 1 8}$ \\
\cline { 2 - 5 } & $\mathbf{2 0 1 7}$ & $\mathbf{2 0 1 8}$ & $\mathbf{2 0 1 7}$ & $\mathbf{2 0 1 7}$ & $\mathbf{2 0 1 8}$ \\
\hline Control & $0.793 \mathrm{a}$ & $0.78 \mathrm{a}$ & $0.83 \mathrm{a}$ & $0.81 \mathrm{a}$ & $550 \mathrm{a}$ & $535 \mathrm{a}$ \\
Site 1 & $0.329 \mathrm{~b}$ & $0.597 \mathrm{e}$ & $0.63 \mathrm{e}$ & $0.615 \mathrm{e}$ & $315 \mathrm{e}$ & $300 \mathrm{e}$ \\
Site 2 & $0.589 \mathrm{ab}$ & $0.654 \mathrm{~d}$ & $0.679 \mathrm{~d}$ & $0.654 \mathrm{~d}$ & $354 \mathrm{~d}$ & $344 \mathrm{~d}$ \\
Site 3 & $0.63 \mathrm{ab}$ & $0.675 \mathrm{c}$ & $0.73 \mathrm{c}$ & $0.712 \mathrm{c}$ & $387 \mathrm{c}$ & $364 \mathrm{c}$ \\
Site 4 & $0.069 \mathrm{a}$ & $0.73 \mathrm{~b}$ & $0.78 \mathrm{~b}$ & $0.743 \mathrm{~b}$ & $420 \mathrm{~b}$ & $400 \mathrm{~b}$ \\
LSD $\mathbf{0 . 0 5}^{\text {20 }}$ & 0.329 & 0.009 & 0.033 & 0.011 & 5.49 & 2.45 \\
\hline
\end{tabular}

With regard to fruit quality the data in Table (8) indicated that control of Washington navel orange fruits had significantly higher vitamin c, total soluble solid and acidity than those of four sites. Also, significant differences were found among the four sites in vitamin $\mathrm{c}$ and total soluble solids content of studied parameters which increased by increasing distance from the electricity power station whereas acidity content was significantly increased in plants in site four $(1 \mathrm{~km})$ when compared with other sites in both seasons. However, total soluble solid /acidity in fruits in the first site $(250 \mathrm{~m})$ was significantly the highest in the first season and higher than fruits in the control and site four $(1 \mathrm{~km})$ in the second season. These results are in line with those obtained by Okwu and Emenike (2006) who reported that The content of $\mathrm{Vc}$ is a reflection of the nutritional value of the fruit. Also, Cheng et al. (2015) found that The contents of Total acidity, TSS and Vc in the navel orange pulp 
ranged from $0.4 \%$ to $0.9 \%, 10.2 \%$ to $16.3 \%$ and 31.1 to $69.2 \mathrm{mg} 100 \mathrm{~g}^{-1}$, with averages of $0.60 \%$, $12.8 \%$ and $47.1 \mathrm{mg} 100 \mathrm{~g}^{-1}$, respectively.

Table 8: Effects of air pollution on fruit vitamin c, total soluble solid ,acidity and total soluble solid /acidity of Washington navel orange at different sites under study.

\begin{tabular}{|c|c|c|c|c|c|c|c|c|}
\hline \multirow[t]{2}{*}{ Sites } & \multicolumn{2}{|c|}{ VC $\mathbf{m g} / \mathbf{1 0 0 m l j u i c e ~}$} & \multicolumn{2}{|c|}{ TSS $\%$} & \multicolumn{2}{|c|}{ Acidity\% } & \multicolumn{2}{|c|}{ TSS/Acidity ratio } \\
\hline & 2017 & 2018 & 2017 & 2018 & 2017 & 2018 & 2017 & 2018 \\
\hline Control site & $53 a$ & $51 \mathrm{a}$ & $13.1 \mathrm{a}$ & $12.9 \mathrm{a}$ & $1.2 \mathrm{a}$ & $1.1 \mathrm{a}$ & $10.92 \mathrm{c}$ & $11.73 b$ \\
\hline Site 1 & $36.44 \mathrm{e}$ & $34.85 \mathrm{e}$ & $11.5 \mathrm{~d}$ & $11 d$ & $0.851 \mathrm{~d}$ & $0.829 \mathrm{c}$ & $13.51 \mathrm{a}$ & $13.27 \mathrm{a}$ \\
\hline Site 2 & $39.61 d$ & $39.36 \mathrm{~d}$ & $11.9 \mathrm{c}$ & $12 \mathrm{c}$ & $0.969 \mathrm{c}$ & $0.925 b$ & $12.28 \mathrm{~b}$ & $12.99 \mathrm{a}$ \\
\hline Site 3 & $45.49 \mathrm{c}$ & $44.16 \mathrm{c}$ & $12.5 b$ & $12.2 \mathrm{bc}$ & $0.985 \mathrm{c}$ & $0.974 b$ & $12.69 \mathrm{~b}$ & $12.52 \mathrm{a}$ \\
\hline Site 4 & $48.41 \mathrm{~b}$ & $47.41 \mathrm{~b}$ & $12.8 \mathrm{ab}$ & $12.5 \mathrm{ab}$ & $1.13 \mathrm{~b}$ & $1.09 \mathrm{a}$ & $11.33 \mathrm{c}$ & $11.49 \mathrm{~b}$ \\
\hline LSD $_{0.05}$ & 0.869 & 1.72 & 0.343 & 0.406 & 0.021 & 0.063 & 0.44 & 0.787 \\
\hline
\end{tabular}

The data in Table (9) illustrated that juice Volume, reduced sugar, non reduced sugar and total sugar of Washington navel orange of control fruits were significantly higher than those of other sites . Also, significant differences were found among the four sites in juice Volume, reduced sugar, non reduced sugar and total sugar of Washington navel orange fruits which increased by increasing distance from the electricity power station in both seasons. In the same line Canas et al. (1997) reported that banana and corn plants exposed to air pollutants had lower contents of total sugars than controls. The reduction in the sugars of banana and corn plants subjected to the effect of air pollutants, is an observation that seems in-conformity with the results of Mostafa et al (1 993). Also ,Fahmyi et al (2004) revealed that the contents of sugars of the target plants were decreased in the polluted sites compared to the plants growing in non-polluted sites.

Table 9: Effects of air pollution on Juice Volume, Reduced sugar, non reduced sugar and Total sugar of Washington navel orange at different sites under study.

\begin{tabular}{lcccccccc}
\hline Sites & $\begin{array}{c}\text { Juice Volume } \\
(\mathbf{m l})\end{array}$ & \multicolumn{2}{c}{$\begin{array}{c}\text { Reduced sugar } \\
(\%)\end{array}$} & \multicolumn{2}{c}{$\begin{array}{c}\text { non reduced sugar } \\
(\%)\end{array}$} & \multicolumn{2}{c}{$\begin{array}{c}\text { Total sugar } \\
(\%)\end{array}$} \\
& $\mathbf{2 0 1 7}$ & $\mathbf{2 0 1 8}$ & $\mathbf{2 0 1 7}$ & $\mathbf{2 0 1 8}$ & $\mathbf{2 0 1 7}$ & $\mathbf{2 0 1 8}$ & $\mathbf{2 0 1 7}$ & $\mathbf{2 0 1 8}$ \\
\hline Control site & $139 \mathrm{a}$ & $135 \mathrm{a}$ & $1.47 \mathrm{a}$ & $1.51 \mathrm{a}$ & $1.84 \mathrm{a}$ & $1.96 \mathrm{a}$ & $3.31 \mathrm{a}$ & $3.47 \mathrm{a}$ \\
Site 1 & $95 \mathrm{e}$ & $90 \mathrm{e}$ & $1.16 \mathrm{~d}$ & $1.14 \mathrm{e}$ & $1.43 \mathrm{e}$ & $1.47 \mathrm{e}$ & $2.59 \mathrm{e}$ & $2.62 \mathrm{e}$ \\
Site 2) & $110 \mathrm{~d}$ & $105 \mathrm{~d}$ & $1.29 \mathrm{c}$ & $1.22 \mathrm{~d}$ & $1.55 \mathrm{~d}$ & $1.59 \mathrm{~d}$ & $2.84 \mathrm{~d}$ & $2.81 \mathrm{~d}$ \\
Site3 & $115 \mathrm{c}$ & $113 \mathrm{c}$ & $1.34 \mathrm{c}$ & $1.33 \mathrm{c}$ & $1.61 \mathrm{c}$ & $1.72 \mathrm{c}$ & $2.95 \mathrm{c}$ & $3.05 \mathrm{c}$ \\
Site4 & $128 \mathrm{~b}$ & $125 \mathrm{~b}$ & $1.41 \mathrm{~b}$ & $1.44 \mathrm{~b}$ & $1.75 \mathrm{~b}$ & $1.81 \mathrm{~b}$ & $3.16 \mathrm{~b}$ & $3.25 \mathrm{~b}$ \\
LSD0.05 & 3.52 & 3.42 & 0.051 & 0.034 & 0.039 & 0.025 & 0.081 & 0.049 \\
\hline
\end{tabular}

The results presented in Table (10) showed that fruit pulp nitrogen, phosphorus and potassium of control plants were significantly higher than those in plants of other sites. Also, significant differences were found among the four sites as fruit nitrogen, phosphorus and potassium increased in the far distance.

Table 10: Effects of air pollution on fruit pulp nitrogen, phosphorus and potassium of Washington navel orange at different sites under study.

\begin{tabular}{lcccccc}
\hline Sites & \multicolumn{3}{c}{$\mathbf{N \%}$} & \multicolumn{2}{c}{$\mathbf{P \%}$} & \multicolumn{2}{c}{ K\% } \\
\cline { 2 - 7 } & $\mathbf{2 0 1 7}$ & $\mathbf{2 0 1 8}$ & $\mathbf{2 0 1 7}$ & $\mathbf{2 0 1 8}$ & $\mathbf{2 0 1 7}$ & $\mathbf{2 0 1 8}$ \\
\hline Control site & $2.44 \mathrm{a}$ & $2.3 \mathrm{a}$ & $0.71 \mathrm{a}$ & $0.684 \mathrm{a}$ & $1.2 \mathrm{a}$ & $1.15 \mathrm{a}$ \\
Site 1 & $1.67 \mathrm{e}$ & $153 \mathrm{~d}$ & $0.443 \mathrm{e}$ & $0.412 \mathrm{e}$ & $0.34 \mathrm{e}$ & $0.3 \mathrm{e}$ \\
Site 2 & $1.91 \mathrm{~d}$ & $1.72 \mathrm{c}$ & $0.54 \mathrm{~d}$ & $0.506 \mathrm{~d}$ & $0.5 \mathrm{~d}$ & $0.54 \mathrm{~d}$ \\
Site 3 & $2.09 \mathrm{c}$ & $1.98 \mathrm{~b}$ & $0.555 \mathrm{c}$ & $0.539 \mathrm{c}$ & $0.76 \mathrm{c}$ & $0.74 \mathrm{c}$ \\
Site 4 & $2.31 \mathrm{~b}$ & $2.19 \mathrm{a}$ & $0.625 \mathrm{~b}$ & $0.573 \mathrm{~b}$ & $0.9 \mathrm{~b}$ & $0.8 \mathrm{~b}$ \\
LSD $_{\mathbf{0 . 0 5}}$ & 0.013 & 0.16 & 0.007 & 0.012 & 0.034 & 0.025 \\
\hline
\end{tabular}

These results agree with those obtained by Grant and Lafond (1993) who found that due to a low quantity of allowed biological matter, total nitrogen concentration in the closer zones from pollutant source declines. Also, Doganlar and Atmaca (2011) illustrated that N accumulation increases with the distance from the pollutant source, which is below the average limit in soil, also indicating 
degradation of surface soils nearby pollutant source. Also, Dey and Dey (2017) found that high significant positive correlations among the soil nutrient factors NPK with the decrease in distance from the pollutant source. Also, Nitrogen concentrations is increasing with the distance from the pollutant source in both soils and plants but no definite pattern of $\mathrm{P}$ and $\mathrm{K}$ accumulation was found.

In this study, it has been found that there was a significant increase in the heavy metals ( chromium, nickel, cadmium and lead ) in fruit pulp tissues in the four sites in both seasons as compared with control and plants in site one had significantly the highest Table (11). These results are in harmony with those obtained by Dey and Dey (2017) who illustrated that there were high significant negative correlations with the heavy metal concentrations $\mathrm{Pb}, \mathrm{Cd}, \mathrm{Cr}$, and $\mathrm{Ni}$ with the decrease in distance from the pollutant source. Also, Kabata-Pendias (2011) estimated Ni and Cd were $0.1-5$; and $0.05-0.2$ respectively and they were higher than the permissible values. Moreover, Kabata-Pendias (2011) reported that in general, plants readily take up the heavy metals dissolved in soil solutions, and it also may absorb heavy metals by aboveground parts from aerial deposition. In addition, Doganlar and Atmaca (2011) indicated a high ability of citrus plant to absorb the heavy metals from polluted soil, which may cause genotoxicity in plant. Moreover, Al-Safawi et al. (2014) found that citrus trees grow in the industrial areas and main streets were containing high concentrations of heavy metals in their tissues. Heavy metals exceeded the maximum permissible limit.

Amer et al. (2019) reported that detection limits of heavy metals were $0.1,0.02,0.1$ and 0.06 $\mathrm{mg} / \mathrm{kg}$ for $\mathrm{Pb}, \mathrm{Cd}$, , $\mathrm{Ni}$ and $\mathrm{Cr}$, respectively and concentrated heavy metals $(\mathrm{mg} / \mathrm{kg})$ in orange samples collected from four Egyptian governorates . They found that $\mathrm{Ni}$ was also detected in orange samples at a concentration of 031 , and $0.38 \mathrm{mg} / \mathrm{kg}$ from Cairo and Giza governorates respectively, Nickel in orange was below the maximum residue limit $(0.20 \mathrm{mg} / \mathrm{kg})$ for samples obtained from Alexandria and $(0.16$ and $0.06 \mathrm{mg} / \mathrm{kg})$ samples obtained from El-Fayoum governorates. Moreover, Maximum residue limit was 0.05 amd 0.1 for cadmium and lead respectively (European commission 1881/2006629/2008) and 0.1 and 0.2 for chromium and nickel, respectively (WHO/FAO). In addition, permissible levels allowed in food $(\mathrm{mg} / \mathrm{kg})$ were $0.2,0.3$ and 66.9 for cadmium, lead and nickel ,respectively (WHO/FAO ). Sobukola et al. (2010) observed that the (pb) in fruit about $904 \mathrm{ppm}$.

Table 11: Effects of air pollution on fruit pulp chromium, nickel, cadmium and lead of Washington navel orange at different sites under study.

\begin{tabular}{lcccccccc}
\hline \multirow{2}{*}{ ites } & \multicolumn{2}{c}{ Pb (ppm) } & \multicolumn{2}{c}{ Ni (ppm) } & \multicolumn{2}{c}{ Cd (ppm) } & \multicolumn{2}{c}{ Cr (ppm) } \\
\cline { 2 - 8 } & $\mathbf{2 0 1 7}$ & $\mathbf{2 0 1 8}$ & $\mathbf{2 0 1 7}$ & $\mathbf{2 0 1 8}$ & $\mathbf{2 0 1 7}$ & $\mathbf{2 0 1 8}$ & $\mathbf{2 0 1 7}$ & $\mathbf{2 0 1 8}$ \\
\hline Control site & $0 \mathrm{e}$ & $0 \mathrm{e}$ & $0 \mathrm{e}$ & $0 \mathrm{e}$ & 0 & $0 \mathrm{e}$ & $0 \mathrm{~b}$ & $0 \mathrm{e}$ \\
Site 1 & $1121 \mathrm{a}$ & $1160 \mathrm{a}$ & $140.3 \mathrm{a}$ & $142.2 \mathrm{a}$ & $45.3 \mathrm{a}$ & $45.8 \mathrm{a}$ & $297.2 \mathrm{a}$ & $301.2 \mathrm{a}$ \\
Site 2 & $733.6 \mathrm{~b}$ & $931.8 \mathrm{~b}$ & $120.3 \mathrm{~b}$ & $127.5 \mathrm{~b}$ & $37.8 \mathrm{~b}$ & $39.8 \mathrm{~b}$ & $296.4 \mathrm{a}$ & $297.7 \mathrm{~b}$ \\
Site 3 & $644 \mathrm{c}$ & $813.5 \mathrm{c}$ & $91.2 \mathrm{c}$ & $110.2 \mathrm{c}$ & $22.3 \mathrm{c}$ & $22.7 \mathrm{c}$ & $295.67 \mathrm{a}$ & $287.5 \mathrm{c}$ \\
Site 4 & $450.1 \mathrm{~d}$ & $560.4 \mathrm{~d}$ & $41.8 \mathrm{~d}$ & $59 \mathrm{~d}$ & $8.5 \mathrm{~d}$ & $13.53 \mathrm{~d}$ & $292.7 \mathrm{a}$ & $285.2 \mathrm{~d}$ \\
LSD $_{\mathbf{0 . 0 5}}$ & 1.79 & 2.12 & 0.827 & 1.71 & 0.168 & 0.338 & 7.11 & 0.984 \\
\hline
\end{tabular}

\section{Conclusion}

The Electricity generation companies are the primary source of greenhouse gases (GHG) emissions around the globe. In order to reduce the GHG emission and to save public health and environment, it is necessary to choose fuel that emit the least $\mathrm{CO}_{2}$ and methane emissions during electricity generation. In this work, heavy metal in citrus fruit and leaves could serve as a baseline data for the assessment of agriculture. Findings suggested that within $0-1000 \mathrm{~m}$ distance from pollutant source might face the maximum threat for environment and agriculture production. Therefore, it is recommended to avoid agricultural production within $0-1000 \mathrm{~m}$ distances from pollutant source due to micronutrient contamination in order to preserve both agriculture, environment and customer health.

\section{Reference}

Abdalla, I. M. F., 2015. Environmental Impact of Red Brick Manufacturing on the Bank of the Blue Nile at Soba West, Khartoum, Sudan. Int .J. Curr. Microbiol. App. Sci., 4(4): 800-804. 
AL-Saffawi, A.Y.T., F. A. AL-Qathelly and K. S. Tawfiq, 2014. Bioaccumulation of Lead element in the shoot of some Plants in Mosul city. Iraq. Third Conference Specialist. Iraq. March, 26-27.

Al-Sallihy, A.A., K.A. Rasheed and Z.A. Azeez, 2016. Heavy Metal Effects from Al-Dura Power Station on Plant Citrus aurantium L. Global Journal of Science Frontier Research: H Environment \& Earth Science Volume 16 Issue 2 Version 23-30.

Amer, M.M.B. A. Sabry, D.A. Marrez, A.S. Hathou and A.S.M. Fouzy, 2019. Exposure assessment of heavy metal residues in some Egyptian fruits. Toxicology Reports 6 (2019) 538-543.

A.O.A.C, 1995. Official Methods of Analysis (A.O.A.C) Pub. By official A.O.A.C chapter 4:18-37, 10: 44: 8-9.

APHA, (American Public Health Association), 1998. Standard methods for the examination of water and waste water. 20th ed. Washington DC.USA.

Bhardwaj, P., A.K. Chaturvedi and P, Prasad, 2009. Effect of enhanced lead and cadmium in soil on physiological and biochemical attributes of (Phaseolus vulgaris L.). National Scientific, 7:6375.

Brown, J.D. and O. Lilliland, 1966. Rapid determination of potassium and sodium in plan material and soil extracts by Flame-photometry. J. Amer. Soc. Hort. Sci., 48: 341-346.

Canas, S.M., A.C. Hebe, O. Liliana and L.P. Maria, 1997. Correlation between environmental conditions and foliar chemical parameters in Ligustrum lucidium Ait. exposed to urban air pollutants. Journal of Environmental Management, 49: 167-191.

Cheng, J. C. Ding, X. Li, T. Zhangand, X. Wang, 2015. Rare Earth Element Transfer from Soil to Navel Orange Pulp (Citrus sinensis Osbeck cv. Newhall) and the Effects on Internal Fruit Quality Published: March 25, 2015 https: //doi. org/ 10.1371 / journal.pone.0120618.

Chou, G. J., 1966. A new method of measuring the leaf area of citrus trees. Acta. Hort. Sci., 1966 5:17-20 (Hort. Abst. 36:7315).

Dey, S and M. Dey, 2017. Soil fertilty loss and heavy metal accumulation and around functional Brick Kilins Cachar istrict Assam, India: A Multivarate Analysis. J.Bio.Innov6 (5), pp: 768781 .

Doğanlar, Z. and M. Atmaca, 2011. Influence of airborne pollution on $\mathrm{Cd}, \mathrm{Zn}, \mathrm{Pb}, \mathrm{Cu}$, and $\mathrm{Al}$ accumulation and physiological parameters of plant leaves in Antakya (Turkey). Water, Air and Soil Pollution, 214:509-523.

Doganlar, Z., O. Doganlar, S. Erdogan, and Y. Onal, 2012. Heavy metal pollution and physiological changes in the leaves of some shrub, palm and tree species in urban areas of Adana, Turkey. Chemical Speciation and Bioavailability, 24(2):65-78.

European Environmental Agency, 2018. European Union emission inventory report 1990-2016 under the UNECE convention on long-range transboundary air pollution (LRTAP). EEA Report No 6/2018. https://doi.org/10.2800/571876.

Evenhuis, B., 1976. Simplified Methods for Foliar Analysis, VII. International Eport, Royal Tropical Institute, Amesterdam.

Evenhuis, B. and P. W. Dewaard, 1980. Principles and Practices in Plant Analysis. FAO Soil Bull., 38(1): 152-163.

Fahmyi, G. M, I .M. Zeid, L.M. Hassanz and E.M .Farahat, 2004. Impact of fuel oil (Mazot) combustion products of brick kilns on Atr quality and on two economic plants. proc. 3'd lnt. Conf. Biol. Sci. (ICBS) Fac. Sci. Tanta Univ. 28 - 29. 3: 25-39.

Fritt-Rasmussen, J., S. Wegeberg, K. Gustavson, K.R. Sørheim, P.S, Daling, K. Jørgensen and J.P. Holst-Andersen, 2018. Heavy Fuel Oil (HFO): A review of fate and behaviour of HFO spills in cold seawater, including biodegradation, environmental effects and oil spill response: Nordic Council of Ministers.

Futch, S. H. and D. P. H. Tucker, 2000. A Guide to Citrus Nutritional Deficiency and Toxicity Identification. Horticultural Sciences Department, UF/IFAS Extension. University of Florida .

Goudarzi, G., S. Geravandi, E. Idani, S.A. Hosseini, M.M. Baneshi, A. R. Yari and A. Ghomeishi, 2016. An evaluation of hospital admission respiratory disease attributed to sulfur dioxide ambient concentration in Ahvaz from 2011 through 2013. Environmental science and pollution research, 23(21):22001-22007.

Grant, C.A and G.P. Lafond, 1993. The effect of tillage and crop Sequences on soil bulk density and penetration resistance on clay soil in Southern Saska Chewan. Can J Soil Sci.73:223-33. 
Greger, M., 1999. Metal availability and bioconcentration in plants. In: Prasad MNV, Hagemeyer J (eds) Heavy metal stress in plants. From molecules to ecosystems, Springer-Verlag, Berlin, 127.

Guerin, J., J., 2004. Toxicity and Health Effects of Chromium (All Oxidation States) L1608_C06.fm Page 213.

Hafeez. B., Y. M. Khanif and M. Saleem, 2013. Role of Zinc in Plant Nutrition- a Review, American Journal of Experimental Agriculture, 3(2): 374-391.

Higazy, M., K. S. M. Essa, F. Mubarak, El-Sayed M. El-Sayed, M. S. Abdelsattar and M. Talaat, 2019. Analytical Study of Fuel Switching from Heavy Fuel Oil to Natural Gas in clay brick factories at Arab Abu Saed, Greater Cairo. Scientific Reports, 9:10081 https:// doi.org/ 10.1038/s41598-019-46587-w.

Hoang Anh, Le, N. and T.O. Kim, 2010 .Integrated assessment of brick kiln emission impacts on air quality Environ. Monit. Assess., 171:381-394.

Horwitz, W., 1972. Official Methods of Analysis Association of Official Analytical Chemists11thed. Washington, D.C.

IS 5182 Part 2 Method of Measurement of Air Pollution: Sulphur Dioxide

Jones, W. and T.W Embleton, 1960. Leaf analysis nitrogen control program for oranges. California Citrograph, 45.

Kabata-Pendias, A., 2011. Trace Elements in Soils and Plants, 4th ed. Taylor \&Francis: London, New York.

Ling, W., Q. Shen, Y. Gao, X. Gu, and Z. Yang, 2007. Uses of bentoniteto control the release of copper from contaminated soils. Australian Journal of Soil Research, 45(8):618-623.

Kanabkaew, T. and K. Buasing, 2015. Assessment of air pollution concentrations from brick kilns using an atmospheric dispersion model. Transactions on Ecology and The Environment, 198 .

Kastori, K., M. Petrovic, N. Petrovic, 1992.Effect of excess $\mathrm{Pb}, \mathrm{Cd}, \mathrm{Cu}$ and $\mathrm{Zn}$ on water relations in sunflower. J. Plant Nutr., 15: 24-27

Kevresan, S., N. Petrovic, M. Popovic, and J. Kandrac, 2001. Nitrogen and protein metabolism in young pea plants as affected by different concentrations of nickel, cadmium, and molybdenum. Journal of Plant Nutr., 24:1633-1644.

Kiran, Y. and A. Sahin, 2005. The effects of the lead on the seed germination, root growth, and root tip cell mitotic divisions of Lensculinaris Medic. Gazi University, Journal of Sci., 18(1):17-25.

Layne, E., 1957. Spectrophotometric and turbidimetric methods for measuring proteins. Methods in Enzymology, 10: 447-455.

Li, F., X. Xiao, W. Xie, D.Ma, Z. Song, and K. Liu , 2018. Estimating air pollution transfer by interprovincial electricity transmissions: The case study of the Yangtze River Delta Region of China, Journal of Cleaner Production 183, 56-66.

Luo, L, Y .Ma, S .Zhang, D .Wei, and Y.G. Zhu, 2009. Inventory of trace element inputs to agricultural soils. J Environ Manage; 90: 2524-30.

Manahan. S.E., 2001. Fundamental of environmental chemistry: Second Edition, Lewis Publishers, USA.

Mehlhorn, H., B.J. Francis, and A.R. Welburn, 1988. Prediction of the probability of forest decline damage lo Nomay spruce using three sample sites-independent diagnostic perimeters. New Phytologist, 110: 525-534.

Melnichuk, Yu . P., A. K .Lishko and F.L. Kalinin, 1982. Cd effect on free amino acid content in germs of pea seeds at early germination stages. Fiziologiya biokhimiya kulturnyh Rasstenii,14: 383-385.

Method 411, Air Sampling and Analysis, 3rd Edition (Determination of oxidizing substances in the atmosphere).

Method IO-2.1 Sampling of Ambient Air for Total Suspended Particulate Matter (SPM) and PM10 Using High Volume (HV) Sampler

Modified, J. and Hochheiser Method (IS 5182 Part 6 Methods for Measurement of Air Pollution: Oxides of nitrogen).

Mostafa, N.M., M.M. Nasralla, Y.M. El Ayouty, and E.A. Ali, 1993. An investigation on some combustion generated pollutants affected plant growth. M.Sc. Thesis, faculty of Science, Zagazig University 
Murphy, J. and J.R .Riley,1962 . A modified single solution method for the determination of phosphour in natural water. Anal. Chem., Acta, 27: 31-38

Nielsen, F. H., 1974, Essentiality and function of nickel, Copyright University Park Press Baltimore, Published in the United Kingdom by Butterworth London 1974.

Nolan, K., 2003. Copper Toxicity Syndrome. The Journal of Orthomolecular Psychiatry, 12, 270-282.

Ogbonna, P.C. and N. Okezie, 2011. Heavy Metal Level and Macronutrient Contents of Roadside Soil and Vegetation in Umuahia, Nigeria. Terrest. Aquat. Environ. Toxicol., 5: 35-

Ogwuegbu, M.O.C. and W. Muhanga, 2005. Investigation of Lead Concentration in the Blood of People in the Copper belt Province of Zambia. J. Environ., 66-75.

Okwu, D.E. and I.N. Emenike, 2006. Evaluation of the phytonutrients and Vitamins content of citrus fruits. Int J Mol Med.2: 1-6.

Paakkbnen, E., S. Seppanen, T. Holopainon, H. Kokoo, S. Kdrenlampi, L. Korenlampi, and J.Kangas-Jfrravi, 1998. Induction of genes for the stress proteins PR-10 and PAL in relation to growth, visible injuries and stomatal conductance in brich (Betuta pendula) clones exposed to ozone and/ordrought. New Phytologist, 138:295-300.

Peralta-Videa, J. R., G. De la Rosa, J. H Gonzalez and J. L. Gardea-Torresdey, 2004. Effect of growth stages on the heavy metal tolerance of alfalfa plants. Adv. Environ. Res., 8:679-685.

Polle, A., M. Mossnang, A.Von schonborn, R. Sladkovic, and H. Rennenberg, 1992. Field studies on Norway spruce trees at high altitudes of needles as affected by climate and pollution. New Phytologist, $121: 89-99$.

Prasad, D.D.K and A.R.K.(Prasad 1987) Altered $\delta$ - aminolevulinic acid metabolism by Pb and Hg in germinating seedlings of Bajra (Pennisetum typhoideum). J. Plant Physiol., 127: 241249.

SAS, 2000. Statistical analyses software version 2000. Raleigh. NC. U. S. A.

Skinder, B.M., A.K. Pandit, A.Q. Sheikh and B.A. Ganai, 2014. Brick kilns: Cause of Atmospheric Pollution. Pollution Effects \& Control, 2(2).

Snedecor, G. and W. G. Cochran, 1990. Statistical methods $7^{\text {th }}$ Ed. The lowa state. Univ. press. Arnes. Lowa. USA. pp: 593.

Sobukola, O. P., O.M. Adeniran, A. A. Odedairo and O. E. Kajihausa, 2010 Heavy metal levels of some fruits and leafy vegetables from selected markets' in Lagos, Nigeria December, African Journal of Food Science, 4(2):389 - 393.

Standard Method- American Public Health Association (APHA), 20th Edition,1998

Streit, B. and W. Stumm, 1993. Plants as Biomontors. Indicators For Heavy Metals in the Terrestrial Environment Market, B(ed.) Weinheim: VCH; 31-62.

Touchette, B.W. and J.M. Burkholder, 2002. Seasonal Variations in Carbon and Nitrogen Constituents in Eelgrass (Zostera marina L.) as Influenced by Increased Temperature and Water- Column Nitrate. Botanica Marina, 45: 23-34.

Turkdogan, M.K., F. Kilicel, K. Kara and I. Tuncer, 2002. Heavy metals in soil, vegetables and fruits in the endemic upper gastrointestinal cancer region of Turkey .Environmental Toxicology and Pharmacology, 13:175-179.

WHO, 2007. Joint FAO/WHO Expert Standards Program Codex Alimentation Commission. Geneva, Switzerland. Available online http://www.who.int [Accessed 10/09/2012].

World Health Organization / Food and Agriculture Organization (JECFA/76/Sc), 2012. $76^{\text {th }}$ Meeting, Geneva WHO/FAO, Summary and Conclusion, Joint FAO/WHO Expert Committee of Food Additives. WHO/FAO, Summary and Conclusion, Joint FAO/WHO Expert Committee of Food Additives.

Yadava, V., 1996. A rapid and nondestructive method to determine chlorophyll in intact leaves. Hort Science 21:1449-1450.

Young, R.A., 2005. Toxicity Profiles: Toxicity Summary for Cadmium. Risk Assessment Information System (RAIS), University of Tennessee. Available at (rais.ornl.gov/tox/ profiles/cadmium. shtml). Accessed 17-12-2010.

Yousefi, N., A. Chehregani, B. Malayeri, B. Lorestani, and M. Cheraghi, 2009. Effect of the heavy metals on the developmental stages of ovule and seed proteins in Chenopodium botrys L. (Chenopodiaceae). Biological Trace Element Research, 144(1-3):1142-1149.

Young, A., and R. Young, 2001. Soils in the Australianlandscape. Melbourne: Oxford University. 
Yurekli, F. and Z.B. Porgali, 2006. The effects of excessive exposure to copper in bean plants. Journal of Acta biologica Cracoviensia. Series: Botanica., 48:7-13.

Zafar, N., M. Athar, M.Z. Iqbai and M. Shafiq, 2016. Effect of diesel generator exhaust pollutants on growth of Vinca rosea and Ruellia tuberosa J. Appl. Sci. Environ. Manage., 20 (4): 1191-1197. 